\title{
El fondo Kati de Tombuctú. Un patrimonio en peligro
}

EI IAPH custodia quince documentos pertenecientes al fondo Kati, considerado uno de los legados más importantes de la cultura andalusí fuera de nuestras fronteras. Afincado en Tombuctú, la amenaza de desertización, primero, y la inestabilidad política de los últimos tiempos, después, han puesto en grave riesgo este fragmento de nuestra historia. La siguiente reflexión indaga sobre los peligros y las medidas que la comunidad internacional está tomando para paliarlos.

María Campoy Naranjo | Centro de Intervención del IAPH

URL de la contribución <www.iaph.es/revistaph/index.php/revistaph/article/view/3409>

Siguiendo las directrices de la Convención sobre el Patrimonio Mundial, Cultural y Natural en su artículo 11.4, la Unesco publica, bajo el nombre Lista del Patrimonio Mundial en Peligro, la relación de sitios de interés patrimonial con alto riesgo de destrucción y deterioro acelerado por factores tan diversos como el desarrollo de proyectos urbanísticos desorbitados y turismo masivo, abandonos y cambio del estado de protección legal, alteración profunda por nuevos usos, desastres naturales o situaciones de conflicto armado.

En la actualidad, una treintena de sitios declarados patrimonio mundial engrosan esta lista, pudiendo el Comité del Patrimonio Mundial, en casos de emergencia, efectuar inscripciones para su difusión inmediata y toma de medidas.

En abril de 2012, Tombuctú, enclave urbano situado en la región norte de la República de Malí, en pleno corazón del Sahel, volvía a entrar precipitadamente en la lista de patrimonios en peligro. La toma de la ciudad por islamistas yihadistas de Ansar Dine con apoyo de otras secciones radicales (combatientes de Monoteísmo y Yihad en África occidental y la rama magrebí de AI Qaeda) pronosticó una situación que apuntaba a la destrucción masiva de monumentos, libros y documentos, confirmándose durante los meses posteriores los peores augurios.

La llamada "perla del desierto", destino de las caravanas del sur y gran centro histórico a orillas de río Níger, conserva entre sus construcciones de barro y adobe un conjunto cultural incomparable. Declarada patrimo- nio mundial en 1988, la Unesco lleva los quince últimos años prestando una atención especial a Tombuctú, cuyos monumentos continúan hoy bajo amenaza por la alarmante y progresiva desertizacion. Las dificultades, nivel de pobreza y estado de conservación propiciaron su inclusión en la Lista de Patrimonio en Peligro, lista en la que permaneció entre los años 1990 y 2005, durante el desarrollo de programas para conservar y proteger la ciudad del avance de las arenas del desierto.

De las entidades culturales afincadas en este rincón de África queremos llamar la atención sobre la Biblioteca Kati, traducción del vocablo africano Quti (godo en español), uno de los fondos de origen andalusí más importantes fuera de nuestras fronteras. Conformado por más de siete mil documentos, buena parte manuscritos en árabe, aljamiado y hebreo, se dio a conocer a la comunidad internacional en el año 1999, tras un largo y costoso proceso de reunificación llevado a cabo por su máximo responsable y presidente de la fundación, Ismael Diadier Haidara, tras ser custodiado y escondido por su familia durante generaciones.

El origen de la colección se remonta a los tiempos de la Reconquista, cuando la delicada convivencia entre cristianos, judíos y musulmanes quedó en entredicho. Su principal artífice, Ali Ben Ziyat al-Quti al-Andalusí, se vio obligado en 1467 a abandonar Toledo, su ciudad natal y la de sus antepasados, rumbo a África. Llevó consigo una valiosa biblioteca compuesta de varios centenares de códices andalusíes que se salvaron de la destrucción masiva instigada por las autoridades cristianas. Atrás 


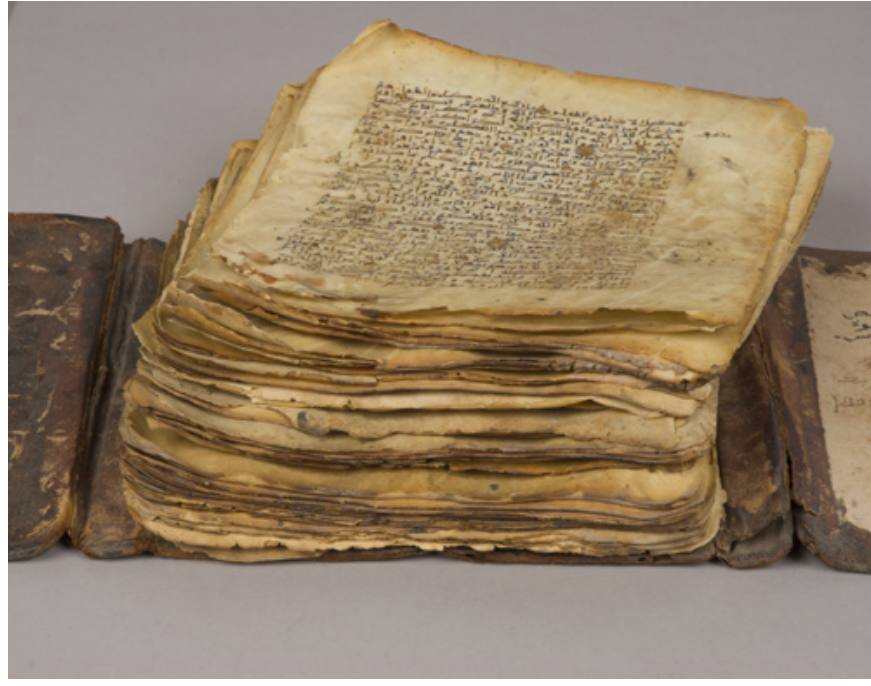

Corán de Ceuta (1198) | foto Fondo Gráfico IAPH (Eugenio Fernández Ruiz)

dejó la Península Ibérica y el Magreb para adentrarse en el África negra, donde terminaba el mundo entonces conocido, estableciéndose en la curva del río Níger, en busca de la paz y tranquilidad que se le negó en España. Sus descendientes continuaron enriqueciendo la colección, cumpliendo con el deseo de sus antepasados de preservar la biblioteca y mantenerla unida.

Son muchas las ocasiones que la colección se ha visto amenazada. En 1612, el avance del imperio del rey marroquí Almanzor aparta a la familia Kati del poder y la lleva a emprender un nuevo exilio. La biblioteca viaja con ellos y, para preservarla, se reparte entre la familia. Estos episodios de dispersión y reunificación se van a repetir a lo largo de los siglos. En la dictadura de Sheik Amadou, la familia Kati y aquellos que no pueden acreditar la limpieza de sangre son perseguidos, confiscados sus libros, para después quemarlos y borrar la memoria de los pueblos del Níger. El clan familiar decide dispersar nuevamente la biblioteca, adoptando el apellido materno para pasar desapercibidos ante el acoso de los peules.

Desaparecida desde 1810, la colonización francesa retoma el interés por la biblioteca Kati pero los manuscritos permanecieron escondidos en humildes casas de barro del delta del Níger hasta que el padre de Diadie Haidara comenzó la última reunificación, siendo su hijo quien logró concluirla. Desde 2003 la biblioteca ocupa un inmueble en Tombuctú habilitado por convenio con la Junta de Andalucía.

Pero la intolerancia va camino de convertirse en la primera amenaza de nuestro tiempo. La inestabilidad política de Malí tras el golpe de estado que revocó al presidente Amodou Toumani Touré y la escalada de violencia islamista tornaron la situación absolutamente hostil. Ismael Diadié y su familia se vieron obligados durante el mes de julio de 2012, a salir precipitadamente de la ciudad dispersando, una vez más, la mayor parte de los manuscritos.

Por fortuna, la biblioteca no se vio afectada por los ataques de los radicales yihadistas, pero no todos los monumentos y centros culturales de Tombuctú corrieron la misma suerte. El Instituto Nacional de Altos Estudios e Investigaciones Islámicas Ahmed Baba sufrió la quema de una parte importante de la documentación histórica, por no mencionar la destrucción del pórtico de la mezquita de Sidi Yayia, y de siete de los dieciséis mausoleos medievales (Sidi Mahmoud, Sidi Moctar, Alpha Moya, Sheij Al Keir entre otros) que dan a Tombuctú el sobrenombre de "la ciudad de los 333 santos".

Si bien, desde 2007, los sitios en peligro reciben apoyo económico del Fondo para el Patrimonio Mundial, situaciones como la que acabamos de exponer reflejan las precarias condiciones en que se encuentra y está sometido el patrimonio histórico de los países inmersos en conflictos bélicos.

La inclusión en la Lista de Patrimonio en Peligro obliga a la UNESCO a desarrollar y adoptar, junto con el país en ciernes, un programa de medidas correctoras y el consiguiente control del estado del sitio, encaminado a devolverlo a la lista ordinaria lo antes posible. Ojalá que no sea necesario que Tombuctú vuelva a engrosar esta ingrata lista. 